\title{
A Comparison of Motorcycle Helmet Wearing Intention and Behavior between Urban and Rural Areas
}

\author{
Sajjakaj Jomnonkwao ${ }^{1, *}$, Duangdao Watthanaklang ${ }^{2}$, Onanong Sangphong ${ }^{2}$, \\ Thanapong Champahom ${ }^{1}{ }^{\mathbb{D}}$, Napat Laddawan ${ }^{1}{ }^{\mathbb{D}}$, Savalee Uttra ${ }^{1}$ \\ and Vatanavongs Ratanavaraha ${ }^{1}$ (i) \\ 1 School of Transportation Engineering, Institute of Engineering, Suranaree University of Technology, \\ Nakhon Ratchasima 30000, Thailand; d5840564@g.sut.ac.th (T.C.); napat.1@g.sut.ac.th (N.L.); \\ savalee.utt@gmail.com (S.U.); vatanavongs@g.sut.ac.th (V.R.) \\ 2 Department of Construction Technology, Faculty of Industrial Technology, \\ Nakhon Ratchasima Rajabhat University, Nakhon Ratchasima 30000, Thailand; \\ duangdao.w@nrru.ac.th (D.W.); onanong.s@nrru.ac.th (O.S.) \\ * Correspondence: sajjakaj@sut.ac.th; Tel.: +66-4422-4238
}

Received: 4 September 2020; Accepted: 10 October 2020; Published: 12 October 2020

\begin{abstract}
The motorcycle is one of the important modes of transport for Thai people in all provinces due to its convenience and ability to access all areas and cover short distances, which is especially convenient for rural people. However, according to the accident record, it was found that the motorcycle was the vehicle causing the highest amount of accidents, and helmet wearing could save lives and reduce the level of severe injuries. In this regard, the objective of this study was to study and develop a model of factors that affected helmet use behavior using structural equation modeling (SEM) based on the Health Belief Model (HBM). Further, this study compared urban and rural models, so as to suggest suitable guidelines for the promotion of helmet use in the study areas. The sample comprised 801 motorcycle users divided into 401 urban residents and 400 rural residents. From the parameter invariance testing in the two areas, a chi-square difference test found differences in the factor loading, intercepts, and structural paths between urban and rural societies.
\end{abstract}

Keywords: helmet wearing intention and behavior; health belief model; structural equation modeling; multigroup analysis; promotion of helmet use

\section{Introduction}

\subsection{Background}

In general, the rate of motorcycle use in developing countries has continued to increase annually [1,2], including Thailand, where usage rates over the past decade have increased up to $38.44 \%$. The number of motorcycles in Thailand increased from 14.5 million vehicles in 2005 to 20.5 million vehicles in 2017 [3]. The widespread use of motorcycles is because they are easy to ride, can access all areas, and are suitable for short-distance travel. They are especially popular among rural residents, often being the first vehicle for new employees [4] who usually have lower wages [5]. Aspects of urban and the rural societies are different towards health behavior. In the past, researchers investigated the difference between urban and rural areas for determining the policies in each area. For example, the role of social support associated with individual psychological well-being [6]. Prudential value influenced happiness and life satisfaction [7]. In Thailand, non-helmeted drivers are illegal. There were some differences between the urban and rural areas, such as in urban areas there is a strict law enforcement 
more than in rural areas. The promoted helmet wearing in rural was less than urban areas, making the two societies different in terms of health perception.

In reference to the total number of road accidents classified by vehicle type, trends indicate that motorcycle crash rates have increased by $24.31 \%$ [8]. The parts of the body that are most susceptible to serious and fatal injuries are the head and face $[9,10]$. Evidence based on reviews indicated that wearing a helmet could prevent death and reduce the severity of injuries [11-13]. Moreover, non-helmeted riders are three times more likely to die than helmeted riders [14]. The use of helmets significantly reduces head and neck injuries and the probability of consequent deaths by $53 \%$ and $72 \%$, respectively [15]. Jou et al. [16] found that motorcyclists are 3.81 times more likely to die in an accident if they are not wearing a helmet. In this regard, the types, standard, and durability of materials used for helmet production also affect the effectiveness of the helmet's defense against impact forces [17,18].

Although it is proven that helmets can prevent and diminish the magnitude of crash severity, and there has been a continuing campaign regarding helmet advantages coupled with the regulations issued by government, helmet use rates have not yet reached 100\% [19]. There have been many studies that have investigated measures to increase helmet use, such as increased law enforcement $[20,21]$ and the participation of communities [22]. Likewise, knowledge provision, awareness creation, and community collaboration may contribute to developing a good attitude toward helmet use. From the results of such studies, helmet use rates have increased from $13.23 \%$ to $44.69 \%$, which has reduced the percentage of fatalities by $6.4 \%$ [22].

From the previous research studying the factors affecting helmet use in motorcycle riders, most of them have studied personal factor, time factor, and law enforcement. For data analysis, they used basic statistical methods. Differently, this study additionally considered social psychological factors and analyzed data by Structural Equation Modeling (SEM) which is an advanced statistic in order to be more accurate in hypothesis testing, prediction, and forecast. The present study aims to determine the factors that influence helmet use in both urban and rural society in Thailand, on the basis of the Health Belief Model. The aim was to discern what factors influence the wearing of helmets in each area, which could assist in identifying the policies required to encourage the wearing of helmets.

\subsection{Health Belief Model}

The Health Belief Model (HBM) has been widely used to explain the factors that influence individual health behavior with an early agreement that individuals will look for and follow health prevention practices such as health inspections or rehabilitation.

According to Rosenstock [23], the HBM consists of four factors: perceived susceptibility to disease, perceived severity of disease, perceived benefits of preventive action, and perceived barriers to preventive action. Maiman and Becker [24] extended these factors and added more details, as the earlier HBM had only been able to predict preventive disease behavior. The HBM of Maiman and Becker [24] has the following factors:

1. Perceived susceptibility to disease means a person's direct beliefs about their behavior. They believe or predict that the risk of contracting diseases or having some level of health problems is related to their sickness avoidance actions. The perception of susceptibility to disease is accepted as the main factor in people's behavior toward good health.

2. Perceived severity of disease means the belief that people have towards their ability to assess the severity of diseases or health problems themselves, which includes such elements as the causes of disabilities, death, difficulties, time-consuming cures, complicated diseases, or the effects on their social roles. The perception of susceptibility to disease (1) accompanied with the perceived severity of disease, (2) allow people to recognize the perceived threat of disease and therefore avoid it.

3. Perceived benefits of preventive action refers to how people search for methods to maintain themselves or to recover from or prevent diseases. The practice must be recognized as good, beneficial, and suitable to prevent susceptibility to disease. The decision to follow suggestions 
depends on comparisons between the advantages and disadvantages of such behavior and choosing that which offers greater advantages.

4. Perceived barriers to preventive action means the beliefs a person has in the possible problems and obstacles that prevent practical behavior and that are connected to the person's negative hygienic health behavior, such as the expense involved and illness. Those people who believe there are many problems create barriers that make behavioral change more difficult.

5. Cue to action means the events that bring about a person's required behavior. Completing the HBM requires a consideration of two sides: internal cues such as the acknowledgement their own body condition, and the symptoms of diseases and sickness, and external cues such as obtaining information through mass media or warnings from loved ones or respected people such as husbands, wives, fathers, and mothers.

6. Modifying factors are factors that do not directly affect health behavior but affect acknowledgement and practice, such as population factors including age and level of education, and sociopsychological factors including health motivation, which could modify an individual's decision to use a helmet.

\subsection{HBM in Transportation Safety Studies}

Table 1 summarizes 11 previous research papers that employed the HMB in transportation safety studies. These include five studies on bicycle helmet use [25-30], four studies on motorcycle helmet use [31-34], and two studies on safety belt use [25,35].

From Table 1, it was found that five studies of which six factors, considered according to HBM, including health motivation, perceived susceptibility, perceived severity, perceived benefits, perceived barriers, and cue to action $[25,26,28,32,33]$. The results of each study were different. Moreover, it was also found that four studies consider the factors according to HBM frame with five factors without considering health motivation $[27,29,34,35]$ of which the results were different. It was also found that four studies considering HBM frame had only one factor which was cue to action [30,31]. Considering the method of data analysis, it was found that there were different methods including Pearson correlation test, OLS regression analysis, two hierarchical regression analyses, text analysis, regression analysis, SEM, exploratory factor analysis, ANOVA, focus group.

From 11 research articles, the factors used in each study generally followed the HBM framework. The levels of statistical significance for these factors are summarized in Table 1, which presents the different findings based on the application of the HBM for bicycles and motorcycle helmet use, safety belt use, or the specified context in each country. 
Table 1. Summary of variables of Health Belief Model (HBM) in previous studies involved in transportation.

\begin{tabular}{|c|c|c|c|c|c|c|c|c|c|}
\hline \multirow[b]{2}{*}{ No. } & \multirow[b]{2}{*}{ Authors (Year) } & \multirow[b]{2}{*}{ Categories } & \multirow[b]{2}{*}{ Analyzed Method } & \multicolumn{6}{|c|}{ Health Belief Model } \\
\hline & & & & $\begin{array}{c}\text { Health } \\
\text { Motivation }\end{array}$ & $\begin{array}{c}\text { Perceived } \\
\text { Susceptibility }\end{array}$ & $\begin{array}{l}\text { Perceived } \\
\text { Severity }\end{array}$ & $\begin{array}{l}\text { Perceived } \\
\text { Benefits }\end{array}$ & $\begin{array}{l}\text { Perceived } \\
\text { Barriers }\end{array}$ & $\begin{array}{l}\text { Cue to } \\
\text { Action }\end{array}$ \\
\hline 1 & $\begin{array}{l}\text { Brijs, Brijs, Sann, Trinh, Wets, } \\
\text { and Ruiter [34] }\end{array}$ & $\begin{array}{l}\text { Motorcycle } \\
\text { helmet use }\end{array}$ & $\begin{array}{l}\text { Pearson correlation test, } \\
\text { OLS regression analysis, } \\
\text { two hierarchical } \\
\text { regression analyses }\end{array}$ & - & $\checkmark^{*}$ & $\checkmark$ & $\checkmark *$ & $\checkmark *$ & $\checkmark$ \\
\hline 2 & $\begin{array}{c}\text { Dennis, Bosson, Peralta, Castillo, } \\
\text { Foran, and Wall [31] }\end{array}$ & $\begin{array}{l}\text { Motorcycle } \\
\text { helmet use }\end{array}$ & Text analysis & - & - & - & - & - & $\checkmark$ \\
\hline 3 & $\begin{array}{l}\text { Aghamolaei, Tavafian, } \\
\text { and Madani [32] }\end{array}$ & $\begin{array}{l}\text { Motorcycle } \\
\text { helmet use }\end{array}$ & Regression analysis & $\checkmark^{*}$ & $\checkmark$ & $\checkmark$ & $\checkmark$ & $J^{*}$ & $\checkmark^{*}$ \\
\hline 4 & $\begin{array}{l}\text { Ali, Haidar, Ali, } \\
\text { and Maryam [35] }\end{array}$ & Safety belt use & Regression analysis & - & $\checkmark *$ & $\checkmark$ & $\checkmark$ & $\boldsymbol{J}^{*}$ & $\checkmark^{*}$ \\
\hline 5 & $\begin{array}{l}\text { Ambak, Ismail, Abdullah, } \\
\text { and Borhan [33] }\end{array}$ & $\begin{array}{l}\text { Motorcycle } \\
\text { helmet use }\end{array}$ & SEM & $\checkmark^{*}$ & $\checkmark$ & $\checkmark$ & $\checkmark$ & $\checkmark$ & $\checkmark$ \\
\hline 6 & $\begin{array}{c}\text { Tavafian, Aghamolaei, Gregory, } \\
\text { and Madani [25] }\end{array}$ & Safety belt use & Regression analysis & $\checkmark$ & $\checkmark$ & $J^{*}$ & $\checkmark *$ & $\checkmark$ & $\checkmark$ \\
\hline 7 & $\begin{array}{l}\text { Ross, Ross, Rahman, } \\
\text { and Cataldo [26] }\end{array}$ & $\begin{array}{l}\text { Bicycle helmet } \\
\text { use }\end{array}$ & $\begin{array}{l}\text { Exploratory factor } \\
\text { analysis, ANOVA }\end{array}$ & $\checkmark$ & $\checkmark$ & $\checkmark$ & $\checkmark$ & $\checkmark$ & $\checkmark$ \\
\hline 8 & $\begin{array}{l}\text { Germeni, Lionis, Davou, } \\
\text { and Th Petridou [27] }\end{array}$ & $\begin{array}{l}\text { Bicycle helmet } \\
\text { use }\end{array}$ & Focus group & - & $\checkmark$ & $\checkmark$ & $\checkmark$ & $\checkmark$ & $\checkmark$ \\
\hline 9 & Lajunen and Räsänen [28] & $\begin{array}{l}\text { Bicycle helmet } \\
\text { use }\end{array}$ & SEM & $\checkmark *$ & $\checkmark$ & $\checkmark *$ & $\checkmark$ & $\boldsymbol{J}^{*}$ & $\checkmark *$ \\
\hline 10 & Quine, Rutter, and Arnold [29] & $\begin{array}{l}\text { Bicycle helmet } \\
\text { use }\end{array}$ & SEM & - & $\checkmark$ & $\checkmark$ & $\checkmark^{*}$ & $\boldsymbol{J}^{*}$ & $\checkmark$ \\
\hline 11 & $\begin{array}{l}\text { Witte, Stokols, Ituarte, } \\
\text { and Schneider [30] }\end{array}$ & $\begin{array}{l}\text { Bicycle helmet } \\
\text { use }\end{array}$ & Correlations & - & - & - & - & - & $\boldsymbol{J}^{*}$ \\
\hline
\end{tabular}




\section{Materials and Methods}

\subsection{Sample Characteristics}

This study was conducted nationwide using simple random sampling. The samples in this study were 801 people (female $53 \%$ and male $47 \%$ ), who rode a motorcycle to study or regular work $(71 \%)$ and for other reasons (29\%), consisted of motorcycle riders (67\%), and motorcycle passengers $(33 \%)$. Types of roads were classified as city streets $(50.06 \%)$ and outside city roads $(49.94 \%)$.

\subsection{Survey Design}

For the structural equation model, Golob [36] has proposed four methods of sampling. This study chose one of methods by considering that the sample size used to estimate maximum likelihood should be at least 15 times the observable variables [37]. From these suggestions, the minimum sample size for this study was $15 \times 20=300$ for each urban and rural group.

The research tool used to collect data was a questionnaire that the researcher constructed using the frameworks of different theories, related research, and the research objectives. The data collection in the field consisted of interviews using questionnaires with two sections. The first section collected general information and traveling behavior data (i.e., gender, trip purpose, road classification, etc.). The second section collected information regarding the attitudes of the motorcycle riders. The attitude toward helmet wearing was studied using the internal relationship of the HBM, the variables for which were perceived susceptibility (i.e., I do not ride a motorcycle at high speed so I need not wear a helmet), perceived benefits (i.e., Wearing a helmet when riding a motorcycle helps me feel safer), perceived severity (i.e., If an accident happens when I am riding a motorcycle without wearing a helmet), cue to action (i.e., I have a lot of friends who regularly wear helmets when riding a motorcycle), perceived barriers (i.e., When wearing a helmet, I feel uncomfortable) and health motivation (i.e., I mostly give importance to safety when riding a motorcycle).

In this study, the samples included motorcycle riders and passengers in urban and rural areas. In the process of data collection, we collected data according to the Thailand's four regions, which included the north region, northeast region, central region, and south region, comprising Chiangrai, Nakhon Ratchasima, Bangkok, and Songkla, respectively, by drawing 200 samples from each province (100 samples from urban society and 100 samples from rural society) with face-to-face interviews conducted in a petrol station.

\subsection{Multigroup Structural Equation Modeling}

The data analysis applied the structural equation model (SEM), which is formulated on the basis of a theory that focuses on the relationship between the latent variables and the observed variables. For the SEM, there is a measurement model and a structural model used to indicate the causal relationship between the variables $[38,39]$. For the SEM methodology, various statistical techniques including factor analysis, path analysis, and regression models were used to analyze the data.

Brown [40] and Koh and Zumbo [41] indicated that multigroup analysis was a popular method for measuring the validity of a structural equation model. The objective is to examine the similarities of population parameters between group A and group B. Byrne [38] and Teo, et al. [42] described a multigroup SEM as a series of consecutive steps. First, the model is fitted and tested separately in each group to determine the consistency of the model results. When the consistency is determined, multigroup testing then proceeds. Second, a chi-square value for a fitted baseline model is computed for the pooled samples in all groups. Third, the constraints, which include loadings, intercepts, and structural paths held equally across groups, are added to the model. The constrained model is fitted, and the chi-square value determined. Finally, a chi-square difference test is applied. The value related to this test represents the difference between the chi-square values for the baseline and other models in which equality constraints have been imposed on particular parameters. This difference value is distributed as a chi-square with the degrees of freedom equal to the difference in the degrees 
of freedom. If this chi-square difference value is statistically significant, evidence of non-invariance is claimed.

\section{Results}

\subsection{Descriptive Statistics}

Table 2 shows the results of basic statistical analysis of observed variable from 20 question items. When considering the value of mean, standard deviation distinguished between urban area and rural area, it was concluded that for urban society, the indicator of health motivation "I think that health is the most important issue" had the highest mean level at $6.47(\mathrm{SD}=0.88)$, followed by perceived severity "If an accident happens when I am riding a motorcycle without wearing a helmet, it may cause my death" $(\mathrm{M}=6.20, \mathrm{SD}=1.03)$, perceived benefits "I believe that motorcycle riders who do not wear helmets have more chances to die" $(\mathrm{M}=6.11, \mathrm{SD}=1.15)$, and the lowest mean level indicator was perceived barriers "I think that when wearing a helmet, it makes me awkward and funny like a crown" $(\mathrm{M}=3.70, \mathrm{SD}=2.07)$ while in rural area, the highest mean level indicator was the factor of Health motivation "I think that health is the most important issue" $(\mathrm{M}=6.22, \mathrm{SD}=1.18)$, followed by "I mostly give importance to safety when riding a motorcycle" $(\mathrm{M}=6.06, \mathrm{SD}=1.19)$, perceived severity "If an accident happens when I am riding a motorcycle without wearing a helmet, it may cause my death" (M = 6.04, $\mathrm{SD}=1.29)$, and the factor having lowest mean was perceived barriers "I think that when wearing a helmet, it makes me awkward and funny like a crown" $(\mathrm{M}=3.65, \mathrm{SD}=1.97)$.

Table 2. Mean and standard deviation of variables used in the model.

\begin{tabular}{|c|c|c|c|c|c|c|c|}
\hline & \multirow{2}{*}{ Variables Used in the Study } & \multicolumn{2}{|c|}{$\begin{array}{l}\text { Urban Society } \\
\quad(n=401)\end{array}$} & \multicolumn{2}{|c|}{$\begin{array}{l}\text { Rural Society } \\
\quad(n=400)\end{array}$} & \multicolumn{2}{|c|}{$\begin{array}{l}\text { Pooled Sample } \\
\quad(n=801)\end{array}$} \\
\hline & & $\mathbf{M}$ & SD & $\mathbf{M}$ & SD & $\mathbf{M}$ & SD \\
\hline & Helmet wearing intention and behavior & \multicolumn{2}{|c|}{$\alpha=0.736$} & \multicolumn{2}{|c|}{$\alpha=0.807$} & \multicolumn{2}{|c|}{$\alpha=0.777$} \\
\hline Item 1 & $\begin{array}{l}\text { In the previous week, I always wore a helmet } \\
(100 \%) \text { when riding, and/or sitting on the back } \\
\text { of a motorcycle }\end{array}$ & 5.75 & 1.28 & 5.66 & 1.41 & 5.71 & 1.35 \\
\hline \multirow[t]{2}{*}{ Item 2} & $\begin{array}{l}\text { Within the next four weeks, I have the intention } \\
\text { to always wear a helmet }(100 \% \text { when riding } \\
\text { and/or sitting on the back of a motorcycle }\end{array}$ & 5.99 & 1.07 & 5.85 & 1.24 & 5.92 & 1.16 \\
\hline & Health motivation & \multicolumn{2}{|c|}{$\alpha=0.753$} & \multicolumn{2}{|c|}{$\alpha=0.801$} & \multicolumn{2}{|c|}{$\alpha=0.784$} \\
\hline Item 3 & I think that street accidents are the worst & 6.19 & 1.07 & 6.01 & 1.21 & 6.10 & 1.15 \\
\hline Item 4 & I think that health is the most important issue & 6.47 & 0.88 & 6.22 & 1.18 & 6.35 & 1.05 \\
\hline \multirow[t]{2}{*}{ Item 5} & $\begin{array}{l}\text { I mostly give importance to safety when riding } \\
\text { a motorcycle }\end{array}$ & 6.22 & 1.01 & 6.06 & 1.19 & 6.14 & 1.11 \\
\hline & Perceived Susceptibility & \multicolumn{2}{|c|}{$\alpha=0.764$} & \multicolumn{2}{|c|}{$\alpha=0.785$} & \multicolumn{2}{|c|}{$\alpha=0.775$} \\
\hline Item 6 & $\begin{array}{l}\text { I do not ride a motorcycle at high speed so I } \\
\text { need not wear a helmet }\end{array}$ & 3.90 & 2.01 & 3.84 & 1.89 & 3.87 & 1.96 \\
\hline Item 7 & $\begin{array}{l}\text { I think that I do not need to wear a helmet when } \\
\text { riding to a nearby place }\end{array}$ & 4.22 & 2.04 & 4.06 & 1.97 & 4.14 & 2.01 \\
\hline \multirow[t]{2}{*}{ Item 8} & $\begin{array}{l}\text { I have experience of riding for several years so I } \\
\text { am able to avoid accidents when riding }\end{array}$ & 4.66 & 1.85 & 4.50 & 1.87 & 4.58 & 1.87 \\
\hline & Perceived Severity & \multicolumn{2}{|c|}{$\alpha=0.861$} & \multicolumn{2}{|c|}{$\alpha=0.867$} & \multicolumn{2}{|c|}{$\alpha=0.886$} \\
\hline Item 9 & $\begin{array}{l}\text { If an accident happens when I am riding a } \\
\text { motorcycle without wearing a helmet, it may } \\
\text { cause my death }\end{array}$ & 6.20 & 1.03 & 6.04 & 1.29 & 6.12 & 1.17 \\
\hline Item 10 & $\begin{array}{l}\text { If an accident happens when I am riding a } \\
\text { motorcycle without wearing a helmet, it may } \\
\text { cause a handicap, a disability, or } \\
\text { time-consuming rehabilitation }\end{array}$ & 6.15 & 1.12 & 5.98 & 1.29 & 6.06 & 1.21 \\
\hline
\end{tabular}


Table 2. Cont.

\begin{tabular}{|c|c|c|c|c|c|c|c|}
\hline & \multirow[t]{2}{*}{ Variables Used in the Study } & \multicolumn{2}{|c|}{$\begin{array}{l}\text { Urban Society } \\
\qquad(n=401)\end{array}$} & \multicolumn{2}{|c|}{$\begin{array}{l}\text { Rural Society } \\
\quad(n=400)\end{array}$} & \multicolumn{2}{|c|}{$\begin{array}{l}\text { Pooled Sample } \\
\quad(n=801)\end{array}$} \\
\hline & & $\mathbf{M}$ & SD & $\mathbf{M}$ & SD & $\mathbf{M}$ & SD \\
\hline \multirow[t]{2}{*}{ Item 11} & $\begin{array}{l}\text { If an accident happens when I am riding a } \\
\text { motorcycle without wearing a helmet, it will } \\
\text { greatly affect my study or my work }\end{array}$ & 6.14 & 1.13 & 5.92 & 1.36 & 6.03 & 1.26 \\
\hline & Perceived Benefits & \multicolumn{2}{|c|}{$\alpha=0.740$} & \multicolumn{2}{|c|}{$\alpha=0.808$} & \multicolumn{2}{|c|}{$\alpha=0.785$} \\
\hline Item 12 & $\begin{array}{l}\text { Wearing a helmet when riding a motorcycle } \\
\text { helps me feel safer }\end{array}$ & 6.08 & 1.08 & 5.88 & 1.33 & 5.98 & 1.22 \\
\hline Item 13 & $\begin{array}{l}\text { A helmet is an efficient accessory for reducing } \\
\text { the severity of injuries when accidents happen }\end{array}$ & 6.06 & 1.09 & 5.76 & 1.32 & 5.91 & 1.22 \\
\hline \multirow[t]{2}{*}{ Item 14} & $\begin{array}{l}\text { I believe that motorcycle riders who do not } \\
\text { wear helmets have more chances to die }\end{array}$ & 6.11 & 1.15 & 5.88 & 1.32 & 6.00 & 1.25 \\
\hline & Perceived Barriers & \multicolumn{2}{|c|}{$\alpha=0.861$} & \multicolumn{2}{|c|}{$\alpha=0.843$} & \multicolumn{2}{|c|}{$\alpha=0.853$} \\
\hline Item 15 & When wearing a helmet, I feel uncomfortable & 4.41 & 1.85 & 4.36 & 1.84 & 4.38 & 1.85 \\
\hline Item 16 & $\begin{array}{l}\text { I think that when wearing a helmet, it makes me } \\
\text { awkward and funny like a crown }\end{array}$ & 3.70 & 2.07 & 3.65 & 1.97 & 3.67 & 2.03 \\
\hline \multirow[t]{2}{*}{ Item 17} & $\begin{array}{l}\text { I think that helmets are too expensive for their } \\
\text { real value or benefits }\end{array}$ & 3.78 & 2.01 & 3.74 & 1.99 & 3.76 & 2.00 \\
\hline & Cue to action & \multicolumn{2}{|c|}{$\alpha=0.701$} & \multicolumn{2}{|c|}{$\alpha=0.643$} & \multicolumn{2}{|c|}{$\mathrm{A}=0.636$} \\
\hline Item 18 & $\begin{array}{l}\text { I have a lot of friends who regularly wear } \\
\text { helmets when riding a motorcycle }\end{array}$ & 5.76 & 1.20 & 5.49 & 1.35 & 5.62 & 1.29 \\
\hline Item 19 & $\begin{array}{l}\text { My parents told me to wear a helmet when I } \\
\text { was young }\end{array}$ & 5.53 & 1.43 & 5.29 & 1.65 & 5.30 & 1.57 \\
\hline Item 20 & $\begin{array}{c}\text { I have seen advertisements on television, signs, } \\
\text { or posters about the importance of wearing a } \\
\text { helmet when riding a motorcycle }\end{array}$ & 5.88 & 1.22 & 5.69 & 1.28 & 5.43 & 1.44 \\
\hline
\end{tabular}

Denote: The response scale for each question was from 1 (strongly disagree) to 7 (strongly agree).

The skewness value and kurtosis for the observed variables was at an acceptable level since the value of the skewedness was not over 2 and that of Kurtosis was not over 7. This showed a normal data distribution. According to data analysis, it was found that every question item was according to the determined requirements.

The reliability of the questionnaires in this study was tested using the Cronbach's Alpha Coefficient of which the accepted criterion was over 0.7 [43], and every latent variable had a Cronbach's Alpha value of more than 0.7. This demonstrated that the construct reliability of the latent variables and could be used to analyze the structural equation modeling (SEM).

From the statistical results of Bartlett's test of sphericity of urban area, which was the statistical testing hypothesis used to test the correlation matrix, the value of $\chi^{2}=3548.427$ ( $\mathrm{df}=190, p<0.001$ ) was found, which was different from 0 at a statistical significance of 0.01 and relevant to the results of the index value for the Kaiser-Meyer-Olkin (KMO) at 0.866, which meant the value approached 1 . With regard to rural society, the statistical results of the Bartlett's test of sphericity for the identity matrix, it was found that the value was $\chi^{2}=3853.991(\mathrm{df}=190, p<0.001)$, which was different from 0 at a statistical significance of 0.01 , and relevant to the results of the index value for the Kaiser-Meyer-Olkin $(\mathrm{KMO})$ of 0.887 , which meant the value approached 1 . This showed that the correlation matrix of observed variables was not an identity matrix and had a sufficient relationship between the variables to analyze the factors using the structural equation model.

\subsection{Multigroup SEM}

The invariance of the parameters was analyzed for urban and rural society models (Table 3). The results for the testing of urban society harmony showed the proportion between the chi-square and the degree of freedom was $1.95\left(\chi^{2}=287.087, \mathrm{df}=147\right)$, while rural society had a proportion between 
the chi-square and the degree of freedom of $\left(\chi^{2} / \mathrm{df}\right) 2.09\left(\chi^{2}=311.825, \mathrm{df}=149\right)$. The assessment of the invariance in the measurement model for the hypothesis testing included factor loading, intercepts, structural paths having no different value using a different value between chi-square and the degree of freedom between the simultaneous model and the strict model. It was found that the different value between the chi-square in the assessment was 59.37, the degree of freedom was 39 , and the $p$-value was 0.019 , so the hypothesis could not be accepted. This indicated that the factor loading, intercepts, and structural paths were different between urban and rural societies.

\subsection{Urban Area $H B M$}

The analysis to determine the factors that affected helmet wearing intention and behavior was conducted using the structural equation model. For urban society, the values were $\chi^{2}=287.087$, $\mathrm{df}=147, p<0.001, \mathrm{CFI}=0.959, \mathrm{TLI}=0.947, \mathrm{SRMR}=0.038$, and RMSEA $=0.049$, as shown in Figure 1 . When compared with the statistical value using the recommended criteria, $\chi^{2}(\mathrm{df})$ should be $p>0.05$ [44], the RMSEA should be 0.06 or less, the CFI should be 0.95 or above, the TLI value should be 0.95 or above, and the SRMR should be 0.08 or less [45]. It was found that every statistical value in the model was measured according to the mentioned criteria except for the chi-square testing as $\chi^{2}$ was found to be sensitive to sample size. For a larger sample size $(n>200)$, the $\chi^{2}$ test tended to reject the hypothesis $[44,46]$. For the previously mentioned reasons and because of the large sample size $(n=400)$, it was concluded that the structural equation modeling had adequate construct validity (fit).

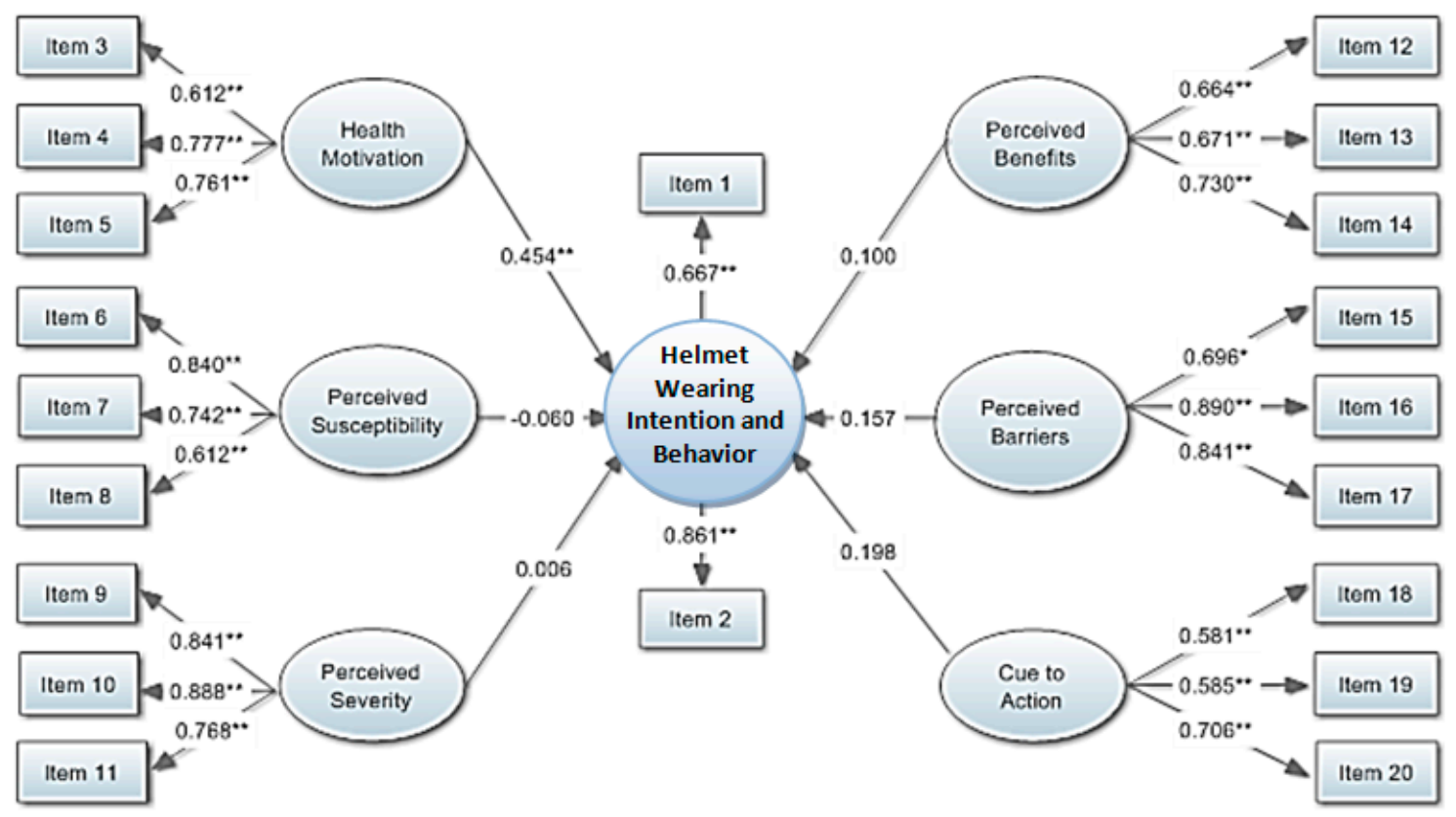

Figure 1. Structural equation modeling of wearing helmets in motorcycle riding for urban society. $\chi^{2}=287.087, \mathrm{df}=147, \chi^{2} / \mathrm{df}=1.95, \mathrm{CFI}=0.959, \mathrm{TLI}=0.947 \mathrm{SRMR}=0.038 \mathrm{RMSEA}=0.049 .{ }^{*} p<0.05$, ** $p<0.01$ (Mplus 7.12 standardized estimates).

When considering the seven measurement models, 20 indicators, all with positive weights, were confirmed as being factors for each latent variable at a statistical significance $(p<0.001)$. This meant that all observed variables had a positive correlation, as shown in Table 4. 
Table 3. Model fit indices for invariance test.

\begin{tabular}{|c|c|c|c|c|c|c|c|c|c|c|}
\hline Description & $x^{2}$ & df & $\chi^{2} / \mathrm{df}$ & CFI & TLI & SRMR & RMSEA $(90 \%$ CI) & Delta- $\chi^{2}$ & Delta-df & $p$ \\
\hline \multicolumn{11}{|l|}{ Individual groups: } \\
\hline Model 1: Urban & 287.087 & 147 & 1.95 & 0.959 & 0.947 & 0.038 & $0.049(0.040-0.057)$ & & & \\
\hline Model 2: Rural & 311.825 & 149 & 2.09 & 0.957 & 0.945 & 0.042 & $0.052(0.044-0.060)$ & & & \\
\hline Measurement of invariance: & & & & & & & & & & \\
\hline Simultaneous model & 584.568 & 294 & 1.98 & 0.960 & 0.948 & 0.040 & $0.050(0.044-0.056)$ & & & \\
\hline $\begin{array}{l}\text { Factor loading, intercepts, structural } \\
\text { paths held equal across groups }\end{array}$ & 643.938 & 333 & 1.93 & 0.957 & 0.951 & 0.052 & $0.048(0.043-0.054)$ & 59.37 & 39 & 0.019 \\
\hline
\end{tabular}

Note: $\chi^{2}=$ chi-squared statistic; $\mathrm{df}=$ degree of freedom; $p=$ level of significance; $\mathrm{CFI}=$ comparative fit index; TLI = Tucker-Lewis index; SRMR = standardized root mean square residual. 
Table 4. Parameter estimates of measurement model.

\begin{tabular}{ccccccccc}
\hline & \multicolumn{5}{c}{ Urban Area } & \multicolumn{5}{c}{ Rural Area } \\
\cline { 2 - 8 } Variable & Estimate & $\begin{array}{c}\text { Standard } \\
\text { Error }\end{array}$ & $p$-Value & $\mathbf{R}^{\mathbf{2}}$ & Estimate & $\begin{array}{c}\text { Standard } \\
\text { Error }\end{array}$ & $p$-Value & $\mathbf{R}^{\mathbf{2}}$ \\
\hline Item 1 & 0.667 & 0.040 & $<0.001$ & 0.445 & 0.731 & 0.031 & $<0.001$ & 0.534 \\
Item 2 & 0.861 & 0.039 & $<0.001$ & 0.741 & 0.933 & 0.027 & $<0.001$ & 0.871 \\
Item 3 & 0.612 & 0.038 & $<0.001$ & 0.375 & 0.707 & 0.031 & $<0.001$ & 0.500 \\
Item 4 & 0.777 & 0.029 & $<0.001$ & 0.604 & 0.783 & 0.027 & $<0.001$ & 0.613 \\
Item 5 & 0.761 & 0.030 & $<0.001$ & 0.579 & 0.779 & 0.027 & $<0.001$ & 0.607 \\
Item 6 & 0.840 & 0.027 & $<0.001$ & 0.705 & 0.829 & 0.029 & $<0.001$ & 0.686 \\
Item 7 & 0.742 & 0.030 & $<0.001$ & 0.551 & 0.695 & 0.033 & $<0.001$ & 0.483 \\
Item 8 & 0.612 & 0.038 & $<0.001$ & 0.375 & 0.704 & 0.034 & $<0.001$ & 0.495 \\
Item 9 & 0.841 & 0.019 & $<0.001$ & 0.707 & 0.867 & 0.017 & $<0.001$ & 0.752 \\
Item 10 & 0.888 & 0.016 & $<0.001$ & 0.788 & 0.864 & 0.017 & $<0.001$ & 0.746 \\
Item 11 & 0.768 & 0.024 & $<0.001$ & 0.590 & 0.763 & 0.024 & $<0.001$ & 0.582 \\
Item 12 & 0.664 & 0.035 & $<0.001$ & 0.440 & 0.793 & 0.024 & $<0.001$ & 0.629 \\
Item 13 & 0.671 & 0.036 & $<0.001$ & 0.451 & 0.763 & 0.027 & $<0.001$ & 0.582 \\
Item 14 & 0.730 & 0.030 & $<0.001$ & 0.533 & 0.731 & 0.029 & $<0.001$ & 0.535 \\
Item 15 & 0.696 & 0.038 & $<0.001$ & 0.484 & 0.752 & 0.028 & $<0.001$ & 0.566 \\
Item16 & 0.890 & 0.028 & $<0.001$ & 0.791 & 0.870 & 0.023 & $<0.001$ & 0.757 \\
Item 17 & 0.841 & 0.028 & $<0.001$ & 0.707 & 0.782 & 0.026 & $<0.001$ & 0.612 \\
Item 18 & 0.581 & 0.042 & $<0.001$ & 0.338 & 0.591 & 0.043 & $<0.001$ & 0.349 \\
Item 19 & 0.585 & 0.042 & $<0.001$ & 0.343 & 0.532 & 0.047 & $<0.001$ & 0.284 \\
Item 20 & 0.706 & 0.037 & $<0.001$ & 0.499 & 0.657 & 0.044 & $<0.001$ & 0.432 \\
\hline
\end{tabular}

Considering the factors that affect helmet wearing intention and behavior based on the HBM for urban area (see Table 5), the results showed that health motivation $(\beta=0.454)$ was the only factor that directly affected helmet wearing intention and behavior at a statistical significance of 0.05 . In other words, if the importance of health and safety for riding was stressed, it would encourage an increase in helmet use for people in urban society. The other five factors-perceived susceptibility, perceived severity, perceived benefits, perceived barriers, and cue to action—did not affect helmet wearing intention and behavior at a statistical significance nor support the HBM framework. 
Table 5. Parameter estimates of structural model.

\begin{tabular}{|c|c|c|c|c|c|c|c|c|c|}
\hline & \multirow[b]{2}{*}{ Hypotheses } & \multicolumn{4}{|c|}{ Urban Area } & \multicolumn{4}{|c|}{ Rural Area } \\
\hline & & $\begin{array}{l}\text { Standardized } \\
\text { Estimates }\end{array}$ & $\begin{array}{l}\text { Standard } \\
\text { Error }\end{array}$ & $p$-Value & Conclusion & $\begin{array}{l}\text { Standardized } \\
\text { Estimates }\end{array}$ & $\begin{array}{l}\text { Standard } \\
\text { Error }\end{array}$ & $p$-Value & Conclusion \\
\hline 1 & $\begin{array}{c}\text { Health motivation } \rightarrow \text { Helmet } \\
\text { wearing intention and behavior }\end{array}$ & 0.454 & 0.102 & $<0.001^{* *}$ & Supported & 0.046 & 0.092 & 0.620 & $\begin{array}{c}\text { Not } \\
\text { supported }\end{array}$ \\
\hline 2 & $\begin{array}{l}\text { Perceived susceptibility } \rightarrow \text { Helmet } \\
\text { wearing intention and behavior }\end{array}$ & -0.060 & 0.082 & 0.463 & $\begin{array}{l}\text { Not } \\
\text { supported }\end{array}$ & -0.039 & 0.068 & 0.563 & $\begin{array}{l}\text { Not } \\
\text { supported }\end{array}$ \\
\hline 3 & $\begin{array}{c}\text { Perceived severity } \rightarrow \text { Helmet } \\
\text { wearing intention and behavior }\end{array}$ & 0.006 & 0.130 & 0.961 & $\begin{array}{c}\text { Not } \\
\text { supported }\end{array}$ & 0.263 & 0.109 & $0.016^{*}$ & Supported \\
\hline 4 & $\begin{array}{l}\text { Perceived benefits } \rightarrow \text { Helmet } \\
\text { wearing intention and behavior }\end{array}$ & 0.100 & 0.280 & 0.722 & $\begin{array}{c}\text { Not } \\
\text { supported }\end{array}$ & 0.253 & 0.123 & $0.040 *$ & Supported \\
\hline 5 & $\begin{array}{c}\text { Perceived barriers } \rightarrow \text { Helmet } \\
\text { wearing intention and behavior }\end{array}$ & 0.157 & 0.084 & 0.062 & $\begin{array}{c}\text { Not } \\
\text { Supported }\end{array}$ & 0.029 & 0.064 & 0.650 & $\begin{array}{c}\text { Not } \\
\text { supported }\end{array}$ \\
\hline 6 & $\begin{array}{c}\text { Cue to action } \rightarrow \text { Helmet wearing } \\
\text { intention and behavior }\end{array}$ & 0.198 & 0.189 & 0.296 & $\begin{array}{l}\text { Not } \\
\text { supported }\end{array}$ & 0.258 & 0.114 & 0.024 * & Supported \\
\hline
\end{tabular}

Note: ${ }^{* *}$ Standardized Estimates is significant at the 0.01 level (two-tailed). ${ }^{*}$ Standardized Estimates is significant at the 0.05 level (two-tailed). 


\subsection{Rural Area HBM}

The analysis to determine the factors that affected helmet wearing intention and behavior using the structural equation model in each rural society group was as follows: $\chi^{2}=311.825, \mathrm{df}=149$, $p<0.001, \mathrm{CFI}=0.957, \mathrm{TLI}=0.945, \mathrm{SRMR}=0.042$, RMSEA $=0.052$, as shown in Figure 2 , in which it can be seen that every value passed the criteria determined in Section 3.3. This demonstrated that the structural equation model was relevant to the empirical data.

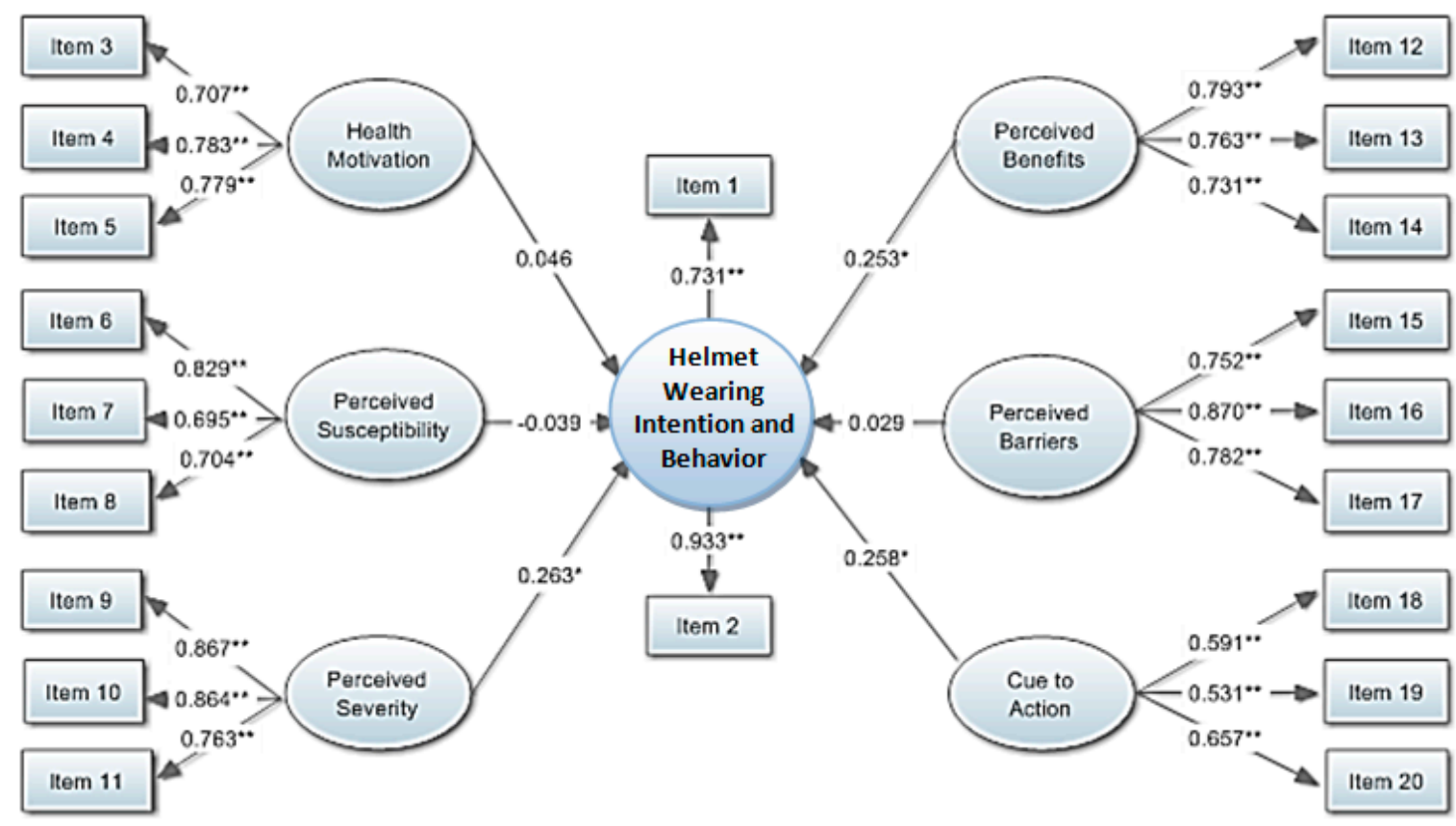

Figure 2. Structural equation modeling of wearing helmets in motorcycle riding for rural society. $\chi^{2}=311.825, \mathrm{df}=149, \chi^{2} / \mathrm{df}=2.09, p<0.001, \mathrm{CFI}=0.957, \mathrm{TLI}=0.945, \mathrm{SRMR}=0.042, \mathrm{RMSEA}=0.052$, ${ }^{*} p<0.05,{ }^{* *} p<0.01$ (Mplus 7.12 standardized estimates).

When considering the seven measurement models, it was found that all 20 indicators were confirmed as factors for each latent variable at a statistical significance $(p<0.001)$, as shown in Table 4 .

Considering the factors affecting helmet wearing intention and behavior based on the HBM for rural society in Table 5, it was found that the three factors that influenced helmet wearing intention and behavior at a statistical significance of 0.05 were perceived severity $(\beta=0.263)$, cue to action ( $\beta=0.258)$, and perceived benefits $(\beta=0.253)$.The other three factors-health motivation, perceived barriers, and perceived susceptibility—did not affect helmet wearing intention and behavior at a statistical significance.

\section{Discussion and Conclusions}

This present study aimed to determine the factors that affected helmet wearing behavior using a structural equation model based on the Health Belief Model. The study was conducted across the two groups of urban society $(n=401)$ and rural society $(n=400)$. Six factors-health motivation, cue to action, perceived barriers, perceived benefits, perceived severity, and perceived susceptibility-were considered the suitable factors for the Health Belief Model (HBM) to test helmet wearing intention and behavior. When comparing the factors that influenced helmet-wearing behavior in urban and rural societies, this study analyzed the invariance of the two models using different chi-squared testing, which allowed for a comparison of the differences between the chi-squared value and the degree of freedom for the baseline model and the strict model. The results found that the chi-squared value difference was 59.37 and the degree of freedom was $39(p=0.019)$. This indicated that the parameters 
of the models for urban society and rural society were different at a statistical significance of 0.05 . From these results, it can be concluded that it is necessary to develop separate helmet use models for urban society and rural society.

According to the SEM, it was found that health motivation was the only factor influencing helmet wearing intention and behavior in urban areas at a statistical significance of 0.05 , which was in line with the studies of Aghamolaei, Tavafian and Madani [32], Ambak, Ismail, Abdullah, and Borhan [33], and Lajunen and Räsänen [28]. When considering the latent variables in the measurement model, it was found that Item 4, "I think that health is the most important issue," had the highest standardized factor loading value (0.783). This indicated that the government sector should give primary importance to developing policies that focus on the perceived importance of health in urban society, which could encourage greater helmet use. However, the policy implications of Item 3 and Item 5 must not be ignored, as both indicators were also confirmed as being health motivation factors at a statistical significance.

For rural society, three factors-perceived severity, cue to action, and perceived benefits-were found to influence helmet wearing intention and behavior at a statistical significance of 0.05 . Perceived severity was in line with the studies of Lajunen and Räsänen [28] and Item 9, "If the accident happens when I ride a motorcycle without wearing a helmet, it may cause mortality," was the indicator with the highest standardized factor loading value (0.867) in the measurement model. Therefore, with this in mind, policy makers must build a course of action that encourages those in rural society to perceive the severe dangers and possible mortality of riding without a helmet.

The cue to action finding was in line with the results of the studies of Aghamolaei, Tavafian, and Madani [32], Tavafian, Aghamolaei, Gregory, and Madani [25], Lajunen and Räsänen [28], and Witte, Stokols, Ituarte, and Schneider [30]. In the measurement model, it was found that Item 20, "I see advertisements on televisions, signs, [and] posters about the importance of wearing helmets when riding a motorcycle during the past time period," was the indicator with the highest standardized factor loading value (0.657). This indicated that promoting the wearing of helmets was very important to encourage increased helmet use in rural areas.

The perceived benefits finding was in line with the results of the studies of Brijs, Brijs, Sann, Trinh, Wets, and Ruiter [34] and Quine, Rutter, and Arnold [29]. In the measurement model, it was found that Item 12, "Wearing a helmet when riding a motorcycle helps me feel safer," was the indicator with the highest standardized factor loading value. Therefore, policies need to be developed that encourage people to perceive the benefits of wearing helmets when riding.

The helmet use model in urban society was found to be significantly different from that of rural society. Therefore, the focused policies also need to be different. For urban society, the promotion of the health benefits must be emphasized, whereas for rural society, people who do not wear helmets must be warned about the risks of disability and death from accidents and how the wearing of helmets can reduce the severity of accidents. It was also found that the motivation for putting helmet wearing into practice comes from friends, families, and mass media. Friends or families' regular helmet use and encouragement regarding the importance of wearing a helmet would encourage greater helmet use.

\section{Limitations and Future Research Studies}

The limitations of this study were the other unstudied factors, such as the regional variables, as Thailand has different geographical, climatic, and traffic profiles, all of which could affect the different models in each region. These variables are a focus for future studies. The surveying of this study was conducted only in the gas station; the future study could add other places, such as schools, shopping malls, and market areas, with various samples. This present study was not able to analyze the regional differences as the samples were too small for each region. Further, studying the factors that influence helmet wearing using the Theory of Planned Behavior (TPB) is also an interesting issue for further study. Moreover, the differences between the riders and the passengers should be additionally studied in order to propose the suitable policy promoting helmet wearing. 
Author Contributions: Conceptualization, S.J.; Data curation, S.J., D.W. and O.S.; Formal analysis, T.C., N.L. and S.U.; Funding acquisition, S.J.; Methodology, S.J. and T.C.; Supervision, V.R.; Writing-original draft, S.J. and D.W.; Writing - review and editing, V.R. All authors have read and agreed to the published version of the manuscript.

Funding: This research was funded by the Suranaree University of Technology Research and Development Fund, grant number RU7-706-59-03 and APC was funded by the Suranaree University of Technology.

Acknowledgments: The authors would like to thank the Suranaree University of Technology Research and Development Fund.

Conflicts of Interest: On behalf of all authors, the corresponding author states that there is no conflict of interest.

\section{References}

1. Sheikh Abdul Kadir, I. Modeling Mode Choice Behavior of Motorcyclists in Malaysia. Ph.D. Thesis, Universiti Putra Malaysia, Putra, Malaysia, 2006.

2. Yuen, C.W.; Karim, M.R.; Saifizul, A. Investigation on motorcyclist riding behaviour at curve entry in the down slope terrain. KSCE J. Civ. Eng. 2015, 19, 749-755. [CrossRef]

3. Department of Land Transport. Transport Statistics. Available online: http://apps.dlt.go.th/statistics_web/ statistics.html (accessed on 19 January 2019). (In Thai)

4. Hsu, T.-P.; Sadullah, A.F.M.; Dao, N.X. A Comparison Study on Motorcycle Traffic Development in Some Asian Countries-Case of Taiwan, Malaysia and Vietnam; The Eastern Asia Society for Transportation Studies (EASTS): Tokyo, Japan, 2003.

5. Chen, C.-F.; Lai, W.-T. The effects of rational and habitual factors on mode choice behaviors in a motorcycledependent region: Evidence from Taiwan. Transp. Policy 2011, 18, 711-718. [CrossRef]

6. Liu, H.; Li, S.; Xiao, Q.; Feldman, M.W. Social Support and Psychological Well-Being Under Social Change in Urban and Rural China. Soc. Indic. Res. 2013, 119, 979-996. [CrossRef]

7. Liang, Y.; Wang, P. Influence of Prudential Value on the Subjective Well-Being of Chinese Urban-Rural Residents. Soc. Indic. Res. 2013, 118, 1249-1267. [CrossRef]

8. Bureau of Highway Safety. Road Accident Statistics. Available online: http://bhs.doh.go.th/statistic/type (accessed on 19 January 2019). (In Thai)

9. Eid, H.O.; Barss, P.; Adam, S.H.; Torab, F.C.; Lunsjo, K.; Grivna, M.; Abu-Zidan, F.M. Factors affecting anatomical region of injury, severity, and mortality for road trauma in a high-income developing country: Lessons for prevention. Injury 2009, 40, 703-707. [CrossRef]

10. Buckley, L.; Bingham, C.R.; Flannagan, C.A.; Carter, P.M.; Almani, F.; Cicchino, J.B. Observation of motorcycle helmet use rates in Michigan after partial repeal of the universal motorcycle helmet law. Accid. Anal. Prev. 2016, 95, 178-186. [CrossRef]

11. Rice, T.M.; Troszak, L.; Ouellet, J.V.; Erhardt, T.; Smith, G.S.; Tsai, B.-W. Motorcycle helmet use and the risk of head, neck, and fatal injury: Revisiting the Hurt Study. Accid. Anal. Prev. 2016, 91, 200-207. [CrossRef]

12. Ramli, R.; Oxley, J. Motorcycle helmet fixation status is more crucial than helmet type in providing protection to the head. Injury 2016, 47, 2442-2449. [CrossRef]

13. Schnegg, M.; Massonnet, G.; Gueissaz, L. Motorcycle helmets: What about their coating? Forensic Sci. Int. 2015, 252, 114-126. [CrossRef]

14. Ouellet, J.V.; Kasantikul, V. Motorcycle Helmet Effect on a Per-Crash Basis in Thailand and the United States. Traffic Inj. Prev. 2006, 7, 49-54. [CrossRef]

15. Keng, S.-H. Helmet use and motorcycle fatalities in Taiwan. Accid. Anal. Prev. 2005, 37, 349-355. [CrossRef] [PubMed]

16. Jou, R.-C.; Yeh, T.-H.; Chen, R.-S. Risk Factors in Motorcyclist Fatalities in Taiwan. Traffic Inj. Prev. 2011, 13, 155-162. [CrossRef] [PubMed]

17. DeMarco, A.L.; Chimich, D.D.; Gardiner, J.C.; Nightingale, R.W.; Siegmund, G.P. The impact response of motorcycle helmets at different impact severities. Accid. Anal. Prev. 2010, 42, 1778-1784. [CrossRef] [PubMed]

18. Fernandes, F.A.O.; Alves de Sousa, R.J. Motorcycle helmets-A state of the art review. Accid. Anal. Prev. 2013, 56, 1-21. [CrossRef] 
19. Nakahara, S.; Chadbunchachai, W.; Ichikawa, M.; Tipsuntornsak, N.; Wakai, S. Temporal distribution of motorcyclist injuries and risk of fatalities in relation to age, helmet use, and riding while intoxicated in Khon Kaen, Thailand. Accid. Anal. Prev. 2005, 37, 833-842. [CrossRef]

20. Branas, C.C.; Knudson, M.M. Helmet laws and motorcycle rider death rates. Accid. Anal. Prev. 2001, 33, 641-648. [CrossRef]

21. Houston, D.J.; Richardson, L.E. Motorcyclist fatality rates and mandatory helmet-use laws. Accid. Anal. Prev. 2008, 40, 200-208. [CrossRef]

22. Ratanavaraha, V.; Jomnonkwao, S. Community participation and behavioral changes of helmet use in Thailand. Transp. Policy 2013, 25, 111-118. [CrossRef]

23. Rosenstock, I.M. Historical Origins of the Health Belief Model. Health Educ. Behav. 1974, 2, 328-335. [CrossRef]

24. Maiman, L.A.; Becker, M.H. The Health Belief Model: Origins and Correlates in Psychological Theory. Health Educ. Behav. 1974, 2, 336-353. [CrossRef]

25. Tavafian, S.S.; Aghamolaei, T.; Gregory, D.; Madani, A. Prediction of Seat Belt Use among Iranian Automobile Drivers: Application of the Theory of Planned Behavior and the Health Belief Model. Traffic Inj. Prev. 2011, 12, 48-53. [CrossRef] [PubMed]

26. Ross, T.P.; Ross, L.T.; Rahman, A.; Cataldo, S. The Bicycle Helmet Attitudes Scale: Using the Health Belief Model to Predict Helmet Use among Undergraduates. J. Am. Coll. Health 2010, 2010, 29-36. [CrossRef] [PubMed]

27. Germeni, E.; Lionis, C.; Davou, B.; Th Petridou, E. Understanding reasons for non-compliance in motorcycle helmet use among adolescents in Greece. Inj. Prev. 2009, 15, 19-23. [CrossRef] [PubMed]

28. Lajunen, T.; Räsänen, M. Can social psychological models be used to promote bicycle helmet use among teenagers? A comparison of the Health Belief Model, Theory of Planned Behavior and the Locus of Control. J. Saf. Res. 2004, 35, 115-123. [CrossRef] [PubMed]

29. Quine, L.; Rutter, D.R.; Arnold, L. Predicting and understanding safety helmet use among schoolboy cyclists: A comparison of the theory of planned behaviour and the health belief model. Psychol. Health 1998, 13, 251-269. [CrossRef]

30. Witte, K.; Stokols, D.; Ituarte, P.; Schneider, M. Testing the Health Belief Model in a Field Study to Promote Bicycle Safety Helmets. Commun. Res. 1993, 20, 564-586. [CrossRef]

31. Dennis, A.C.; Bosson, N.; Peralta, J.E.C.; Castillo, C.; Foran, M.; Wall, S.P. Determinants of helmet wearing behavior among motorcyclists in the Dominican Republic. Int. J. Public Health Epidemiol. 2013, 2, 50-55.

32. Aghamolaei, T.; Tavafian, S.S.; Madani, A. Prediction of Helmet Use among Iranian Motorcycle Drivers: An Application of the Health Belief Model and the Theory of Planned Behavior. Traffic Inj. Prev. 2011, 12, 239-243. [CrossRef]

33. Ambak, K.; Ismail, R.; Abdullah, R.A.; Borhan, M.N. Using structural equation modeling and the behavioral sciences theories in predicting helmet use. In Proceedings of the International Conference on Advanced Science, Engineering and Information Technology, Putrajaya, Malaysia, 14-15 January 2011.

34. Brijs, K.; Brijs, T.; Sann, S.; Trinh, T.A.; Wets, G.; Ruiter, R.A.C. Psychological determinants of motorcycle helmet use among young adults in Cambodia. Transp. Res. Part F Traffic Psychol. Behav. 2014, 26, 273-290. [CrossRef]

35. Ali, M.; Haidar, N.; Ali, M.M.; Maryam, A. Determinants of Seat Belt Use Among Drivers in Sabzevar, Iran: A Comparison of Theory of Planned Behavior and Health Belief Model. Traffic Inj. Prev. 2011, 12, 104-109. [CrossRef]

36. Golob, T.F. Structural equation modeling for travel behavior research. Transp. Res. Part B Methodol. 2003, 37, 1-25. [CrossRef]

37. Stevens, J. Applied Multivariate Statistics for the Social Sciences; Lawrence Erlbaum Associates: Mahwah, NJ, USA, 1996.

38. Byrne, B.M. Structural Equation Modeling with Mplus: Basic Concepts, Applications, and Programming; Taylor and Francis Group: Boca Raton, FL, USA, 2012.

39. Raykov, T.; Marcoulides, G.A. A First Course in Structural Equation Modeling; Lawrence Erlbaum Associates, Inc.: Mahwah, NJ, USA, 2006.

40. Brown, T.A. Confirmatory Factor Analysis for Applied Research; The Guilford Press: New York, NY, USA, 2006; p. 475. 
41. Koh, K.; Zumbo, B. Multi-Group Confirmatory Factor Analysis for Testing Measurement Invariance in Mixed Item Format Data. J. Mod. Appl. Stat. Methods JMASM 2008, 7, 471-477. [CrossRef]

42. Teo, T.; Lee, C.B.; Chai, C.S.; Wong, S.L. Assessing the intention to use technology among pre-service teachers in Singapore and Malaysia: A multigroup invariance analysis of the Technology Acceptance Model (TAM). Comput. Educ. 2009, 53, 1000-1009. [CrossRef]

43. Nunnally, J.C. Psychometric Theory, 2nd ed.; McGraw-Hill: New York, NY, USA, 1978.

44. Kline, R.B. Priciples and Practice of Structural Equation Modeling; Guilford Press: New York, NY, USA, 2011.

45. Hu, L.T.; Bentler, P.M. Cutoff criteria for fit indexes in covariance structure analysis: Conventional criteria versus new alternatives. Struct. Equ. Modeling A Multidiscip. J. 1999, 6, 1-55. [CrossRef]

46. MacCallum, R.C.; Browne, M.W.; Sugawara, H.M. Power analysis and determination of sample size for covariance structure modeling. Psychol. Methods 1996, 1, 130-149. [CrossRef]

(C) 2020 by the authors. Licensee MDPI, Basel, Switzerland. This article is an open access article distributed under the terms and conditions of the Creative Commons Attribution (CC BY) license (http://creativecommons.org/licenses/by/4.0/). 